\title{
The Role of Inventory Management on Financial Performance in some Selected Manufacturing Companies in Mogadishu
}

Abdikani Shire Anshur, Mahad Mohamed Ahmed and Mohamed Hassan Dhodi*

Faculty of Management Science, Department of Accounting, Simad University, Mogadishu-Somalia

*Corresponding author: Mohamed Hassan Dhodi, Faculty of Management Science, Department of Accounting, Simad University, Mogadishu, Somalia; Tel: 252615677900; E-mail: mxdhoodi@gmail.com

Received date: Sep 02, 2018; Accepted date: Sep 11, 2018; Published date: Sep 18, 2018

Copyright: @ 2018 Anshur AS, et al. This is an open-access article distributed under the terms of the Creative Commons Attribution License, which permits unrestricted use, distribution, and reproduction in any medium, provided the original author and source are credited.

\begin{abstract}
In this study, the research team studied the role of inventory management on the financial performance in some selected manufacturing companies in Mogadishu with the major objective of the study is to determine the inventory management practices used in manufacturing firms and to investigate the relationship between inventory management and financial performance in manufacturing firms. The research team selected 72 respondents with the use of questionnaire as instrument and data was analyzed using both descriptive and correlation statistics of mean and frequency (percentage) for SPSS. After gathering and analyzing data, the study found that there is significant positive relationship between the inventory management and financial performance where $r=0.683$.
\end{abstract}

Keywords:Inventory; Inventory management; Financial performance

\section{Introduction}

Inventories are the present resources which are relied upon to be changed within a year in the shape of cash or accounts receivables. For this reason, it's miles a sizable part of the assets for the commercial companies. As a matter of fact, inventories are the merchandise that are supplied and have a resale esteem so as to increase some benefit. Inventory refers to the supply of the assets which are held to deals as well as future generation. Inventory manage suggests the coordination of materials controlling, use and acquiring. It has additionally the reason for getting the correct stock at the opportune place in the perfect time with right amount since it is specifically associated with the creation [1].

Financial performance is a subjective measure of how properly a firm can use resources from its essential method of enterprise and generate sales. The term is additionally utilized as a general measure of a company's general economic health over a given timeframe and can be utilized to analyze comparative firms over a similar industry or to look at ventures or segments in hostility [2].

There is no agreement among the different research on the relationship between inventory performance and financial performance. While one array of the literature indicates that there's a positive relation among the two, other shows that there is no significant relation between the inventory performance and financial performance [3].

\section{Problem Statement}

Associations utilize inventory control not only to guarantee materials and items time accessibility yet additionally to guarantee better customer service and to accomplish competitive advantage. Even as numerous associations utilize inner inventory practices as an approach to accomplish organizational goals for example, upgraded productivity and enhanced acquirement activities, adoption of useful inner inventory control practices have been a challenge to many. There has been a considerable measure of challenges in deciding the coveted stock levels that guarantees a free stream of materials without causing overwhelming costs in stocking those materials and with no stock being rendered out of date [4].

Problems are probably going to raise when inventory is not tracked correctly, wastefulness and extra costs sum. Supplies get lost, shrinkage can move unchecked, stock-outs happen, basic equipment places are indeterminate, charging is wasteful since provisions are utilized without being related to patient's file and onhand inventory can balloon unnecessarily. All of this results in inefficiency and extra expenses [5].

In Somalia, there are numerous troubles for inventory management since inventory is the biggest asset in current asset segment for manufacturing companies. The main trouble of inventory is to utilize more expenses for producing the inventory of the company and it is hard to reduce the great cost of inventory. Additionally, the other issue of stock is misrepresentation from the workers of the organization or different gatherings that can be basis from the neglected or mismanagement of inventory [6].

\section{Objectives of the Study}

- To determine the inventory management practices used in manufacturing firms.

- To investigate the relationship between inventory management and financial performance in manufacturing firms.

\section{Literature Review}

\section{Inventory management}

The expression "inventory" in assembling organizations alludes to the store of the items a firm is putting forth available to be purchased and the segments that make up the item. The assets which organizations store as stock for expectation about require are: raw 
materials, work in progress, finished goods and supplies [7]. Inventory, as a feature of current resources which are relied upon to be changed over to another type of working capital (receivables or cash) within less than multiyear, involve a huge bit of business resources in most business ventures. Remembering this reality done mind, the presence of inventories infers proportionally significant financial investment [8].

Inventory is fundamental to association for production activities, maintenance of plant and machinery and also other operational necessities. This results in tying up of cash or capital which could have been utilized more productively. The administration of an association turns out to be exceptionally worried in inventory stocks are high Inventory is a piece of the organization resources and is constantly reflected in the organization's asset report [9].

Inventory playing an essential part in an associations business and operational execution to meet customer service levels and seasonal demands, an association's capacity to oversee inventory to meet requests while thinking about different drivers including exchange rates, sea and inland cargo, government tax incentives, and natural components will eventually influence the inventory costs incurred by agricultural machinery organizations in the UK [10].

Inventory administration assumes a vital part in each organization as any inadequate inventory framework will bring about misfortune customers and sales. An effective inventory administration can produce more sales for the organization which specifically influences the execution of the organization. Hence it requires a systematic inventory management which is overseen by a gathering of workers who are specialists here [11].

Inventory control infers the coordination of materials controlling, usage and acquiring. It has likewise the reason for getting the correct inventory at the correct place in the perfect time with correct quantity since it is specifically associated with the generation. The goal of any association is to get a decent return out of each cedi invested in the company [12].

\section{Financial performance}

Financial performance shows the financial health and it is a pointer of an association's financial soundness and profitability. Financial performance can be evaluated or computed with different tolls however each measure draws or depicts the diverse part of financial performance. Financial administration rehearses cover an expansive viewpoint to comprehend future financial performance with an approach to augment the benefit and transformation into riches and normally it attempts to underwrite the proficiency of financial resources [13].

Financial performance implies association's general financial wellbeing over a given timeframe. Financial performance analysis is the way toward deciding the working and financial attributes of a firm from accounting and financial statements. The aim of such analysis is to decide the effectiveness and performance of company's administration, as reflected in the financial records and reports. The analyst endeavors to gauge the association's liquidity, productivity and different pointers that the business is performed in a rational and ordinary way; guaranteeing enough returns to the investors to keep up at least its market value [14]

Financial analysis is chiefly done to think about the development, gainfulness and financial soundness of the particular banks by diagnosing the data contained in the financial statements. Financial analysis is done to recognize the financial qualities and shortcomings of the two banks by appropriately setting up connection between the things of Balance Sheet and Profit and Loss Account. It helps in better comprehension of banks financial position, development and execution by examining the financial statements with different devices and assessing the connection between different components of financial statements [15].

\section{Inventory management and financial performance}

Kilonzo, Memba, et al. studied "Effect of Inventory Management on Financial Performance of Firms Funded by Government Venture Capital" in Kenya [16]. The purpose of this study was to determine the effect of inventories management on financial performance of firms funded by government venture capital in Kenya. A structured questionnaire was used to collect data. Descriptive analysis showed the percentages, means and standard deviation of different items in the study while quantitative analysis showed the Pearson correlation, ANOVA and regression analysis. However, the study found that there is more to be done in Kenya on inventory management and especially in the area of management of obsolete inventory as well as review and adherence to sound inventory management policies. Managers can create value for their shareholders by reducing the inventory turnover days to reasonable minimum.

Vipulesh investigated Impact of Inventory Management on the Financial Performance of the firm [1]. The purpose of this study was to decide Impact of Inventory Management on the Financial Performance of the firm in India. All data for this paper is secondary data and taken from various sources. After collecting data from the sources we correlate the inventory turnover with profitability of the firm using correlation concept. So, a manufacturing firm must install the optimal inventory control techniques or improve their asset turnover as much as possible. Also, by different analysis it is concluded that inventory turnover ratio is correlated with the net profit of the companies. Hence, from different findings it is concluded that there is impact of inventory management on the financial condition of the firm.

Timothy, Patrick, et al. examined the impact of inventory management practices on financial performance of sugar manufacturing firms in Kenya [17]. The purpose of this study is to investigate the relationship, if any, between inventory management practices and financial performance of sugar manufacturing firms in Kenya. The study adopted a descriptive research design. A survey was conducted on all the eight sugar manufacturing firms in Kenya. Both Primary and secondary data were used. The primary data was collected using structured and semi-structured questionnaires. The secondary data was obtained from the publications of the Kenya sugar Board and from the annual performance statements available in the Year Book of Sugar Statistics. The findings suggest that there is generally more than average positive correlation between inventory management practices and financial performance of sugar companies.

Jighyasu and Sourabh studied the relationship of financial and inventory performance of manufacturing firms in Indian context [3]. This study examines the relationship between the performance of the discrete components of inventory and the financial performance of Indian manufacturing firms. The method of the study used is regression analysis. The results also show that few industries have positive impact on financial performance but miscellaneous manufacturing is having negative impact on GPS. The results of our study indicate that FGI is an important decisive factor in strategic formation for Indian Manufacturers. Our results also suggest that 
Citation: Abdikani SA, Mahad MA, Mohamed HD (2018) The Role of Inventory Management on Financial Performance in some Selected Manufacturing Companies in Mogadishu. Int J Account Res 6: 179. doi: 10.35248/2472-114X.18.6.179

Page 3 of 6

those managers who do not focus on inventory performance may lose out to their competitors.

According to Vedran et al. established the relationship between inventory and financial performance in manufacturing companies [18]. The purpose of the study is to determine the relationship between inventory and financial performance. The method of this study is regression model. The results of the study show a strong correlation between inventory performance and financial performance across a broad array of manufacturing industries. Performance of total as well as all three discrete components of inventory is positively associated with financial performance. The results show a positive correlation between all the inventory components and improved financial performance, managers should probably focus their efforts on reducing RMI where the relationship is the strongest.

\section{Methodology}

A research design was generally arranged for research task. It concentrated the study method implemented and for this research study with the aim of reaching the research objectives. This research was used by quantitative research design in order to measure the result and to get the important information of the research. The target population for the study was some manufacturing companies in Mogadishu. The preferred companies are Coca cola, Jema Mineral Water and Anshur Factory. For that reason, it is hard for the researchers to decide the exact number of the sample size. So, the researchers used population proportion method because it can determine the appropriate sample size of the study when the population of the study is infinite. So, sample size was 72 respondents.
Where:

$\mathrm{n}=$ size of the sample

$\mathrm{p}=$ sample proportion of success

$(1-\mathrm{p})=$ sample proportion not success

$\mathrm{E}=$ error

$\mathrm{Z}=\mathrm{z}$ test for given confidence level (95\% confidence level).

The research team was used a questionnaire tool for a collecting data, the selecting of these tools have been guided by the nature of data to be collected. The questionnaire adopted from Mohamud who investigated the Inventory management and company's profitability in selected manufacturing companies in Mogadishu, Somalia. The selection of this tool was guided by the nature of data to be collected, the time available as well as by the objectives of the study [19].

In this research, data analyzed through descriptive and correlation statistics by using statistical package for social science (SPSS). Descriptive research gives description regarding the nature of the respondents and it shows the percentages, mean and standard deviation of different items in the study. On other hand, correlation shows the relationship between the two variables. After the researchers collected the data, it entered manually in SPSS worksheet and the information gathered through graphical presentation. Thereafter, the researchers made an interpretation of the frequency, tables and accordingly make a summary of findings, conclusions and recommendations (Table 1).

\begin{tabular}{|l|l|l|}
\hline No & Mean range & Interpretation \\
\hline 1 & 1 up to 1.80 & Strongly disagree \\
\hline 2 & 1.81 up to 2.60 & Disagree \\
\hline 3 & 2.61 up to 3.40 & Not sure \\
\hline 4 & 3.41 up to 4.20 & Agree \\
\hline 5 & 4.21 up to 5.00 & Strongly agree \\
\hline
\end{tabular}

Table 1: Interpretation mean scores.

\section{Findings and Discussions}

\section{Demographic data}

The sample size of the study was 72 respondents. The demographic characteristics of the respondents in the study were gender, age and marital status, level of education and experience of the respondents. After the distributed questionnaire collected and analyzed, we found the following characteristics of the respondents.

\begin{tabular}{|c|c|c|}
\hline & Frequency & Percent \\
\hline \multicolumn{3}{|l|}{ Gender } \\
\hline Male & 53 & $73.61 \%$ \\
\hline Female & 19 & $26.39 \%$ \\
\hline Total & 72 & $100 \%$ \\
\hline
\end{tabular}


Citation: Abdikani SA, Mahad MA, Mohamed HD (2018) The Role of Inventory Management on Financial Performance in some Selected Manufacturing Companies in Mogadishu. Int J Account Res 6: 179. doi:10.35248/2472-114X.18.6.179

Page 4 of 6

\begin{tabular}{|c|c|c|}
\hline $20-30$ & 60 & $83.33 \%$ \\
\hline $31-40$ & 11 & $15.28 \%$ \\
\hline $41+$ & 1 & $1.39 \%$ \\
\hline Total & 72 & $100 \%$ \\
\hline \multicolumn{3}{|c|}{ Marital status } \\
\hline Single & 43 & $59.72 \%$ \\
\hline Married & 23 & $31.94 \%$ \\
\hline Divorced & 6 & $8.33 \%$ \\
\hline Total & 72 & $100 \%$ \\
\hline \multicolumn{3}{|c|}{ Level of education } \\
\hline Diploma & 8 & $11.11 \%$ \\
\hline Bachelor & 55 & $76.39 \%$ \\
\hline Master & 9 & $12.50 \%$ \\
\hline PHD & 0 & 0 \\
\hline Total & 72 & $100 \%$ \\
\hline \multicolumn{3}{|l|}{ Experience } \\
\hline 1-5 Years & 51 & $70.83 \%$ \\
\hline 5-10 Years & 16 & $22.22 \%$ \\
\hline $10+$ & 5 & $6.94 \%$ \\
\hline Total & 72 & $100 \%$ \\
\hline
\end{tabular}

Table 2: Demographic characteristics of the respondents.

As shown in Table 2, the majority of the respondents were male 53 (73.62 \%) while the female were $19(26.39 \%)$. In the age of the respondents, where $60(83.33 \%)$ of them were in 20-30 years, 31-40 years were $11(15.28 \%), 41$ and above were $1(1.39 \%)$. The majority of the respondents were in between the ages of 20 up to 30 years. On the other hand, it shows that majority of the respondents were single 43 $(59.72 \%)$ of total respondent, married persons were $23(31.94 \%)$ of total respondents and the divorced person were 6 (8.33\%).

In the education level of the respondents consisted of Diploma, Bachelor, Master and PHD. The majority of the respondents were bachelor degree holders 55 (76.39\%), master degree holders were 9 $(12.50 \%)$, the diploma holders were $8(11.11 \%)$ of respondents, while there is no PHD holders in the respondents. Also, According to the data collected from the time of the respondents have been working with the company, The majority of the respondents have an experience for a time between one to five years 51 (70.83\%) of the respondents, 16 (22.22\%) of the respondents are working with their companies time between five to ten years, while $5(6.94 \%)$ of the respondents are working with their companies more than ten years.

\section{Data presentation and analysis}

The respondents were asked questions related the objectives of the study and their responses were analyzed and described using Mean and standard deviations.

\section{Inventory management practices used in manufacturing firms}

The first objective of the study was to determine the inventory management practices used in manufacturing firms. In order to attain the objective of the study the researchers developed series statements for questionnaire about the objective that respondents were asked to indicate whether they agree or disagree to questionnaires provided by ticking the number that exactly reflects or close to their opinion. However, the result that researcher collected from the respondents was as follows: 
Citation: Abdikani SA, Mahad MA, Mohamed HD (2018) The Role of Inventory Management on Financial Performance in some Selected Manufacturing Companies in Mogadishu. Int J Account Res 6: 179. doi: 10.35248/2472-114X.18.6.179

Page 5 of 6

\begin{tabular}{|c|c|c|c|c|}
\hline 1 & You pay maximum attention to those inventories whose value is highest & 3.5 & 1.3 & Agree \\
\hline 2 & The company use EDI (electronic data interchange) when dealing with the customers & 3.13 & 1.26 & Not Sure \\
\hline 3 & $\begin{array}{l}\text { The company use EPOS (electronic point of sale systems) in your communication with the } \\
\text { customers }\end{array}$ & 3.32 & 1.33 & Not Sure \\
\hline 4 & The company use Just-In-time (JIT)/lead time for purchasing system of inventory & 3.43 & 1.23 & Agree \\
\hline 5 & The company has computerized all inventory management systems & 3.75 & 1.14 & Agree \\
\hline 6 & The company uses Activity Based Costing analysis techniques & 3.21 & 1.28 & Not Sure \\
\hline 7 & $\begin{array}{l}\text { The staff of the company well trained on the use of Information Technology applications in } \\
\text { inventory management }\end{array}$ & 3.92 & 1.2 & Agree \\
\hline \multicolumn{2}{|c|}{ Overall Mean Index } & 3.46 & 1.25 & Agree \\
\hline
\end{tabular}

Table 3: Inventory management practices used in manufacturing firms.

Based on Table 3, the mean value 3.50 and standard deviation value 1.30 shows that the employees pay maximum attention to the inventories which has more value to the company. On the other hand, the results of whether the company uses EDI (electronic data interchange) when dealing with the customers proves that respondents do not sure using that item by the mean 3.13 and standard deviation 1.26. Also, the results of whether the company uses EPOS (electronic point of sale systems) in their communication with the customers confirms that respondents do not sure using for that electronic and scored it by mean 3.32 and standard deviation 1.33 . The company use Just-In-time (JIT)/lead time for purchasing system of inventory have a mean value 3.43 and standard deviation 1.23 which indicates that the companies use it. The mean value of 3.75 and standard deviation 1.14 explains that the companies have computerized in all inventory management systems. Additionally, the results of the company uses Activity Based Costing analysis techniques illustrates that respondents do not sure to use for it and it scored by a mean 3.21 and standard deviation 1.28. The staff of the company well trained on the use of
Information Technology applications in inventory management have a mean value 3.92 and standard deviation 1.20 that shows to make it. Lastly, the overall mean index of objective one exhibits a Mean of 3.46 and standard deviation of 1.25 which indicates that respondents (managers and staffs) believe that companies use just-in-time and computerized systems in all inventory management. Also, it shows that the staffs of the companies are well trained on the use of Information Technology applications in inventory management.

\section{Relationship between inventory management and financial performance in manufacturing firms}

The second objective of the study was to determine the relationship between inventory management and financial performance in some selected manufacturing firms in Mogadishu, Somalia. In order to attain the objective of the study the researchers developed series statements about the two variables.

\begin{tabular}{|c|c|c|c|}
\hline \multicolumn{4}{|l|}{ Correlations } \\
\hline & & Inventory management & Financial performance \\
\hline \multirow{3}{*}{ Inventory management } & Pearson Correlation & 1 & $0.683^{* *}$ \\
\hline & Sig. (2-tailed) & 0 & 0 \\
\hline & $\mathrm{N}$ & 72 & 72 \\
\hline \multirow{3}{*}{ Financial performance } & Pearson Correlation & 0.683 & 1 \\
\hline & Sig. (2-tailed) & 0 & \\
\hline & $N$ & 72 & 72 \\
\hline
\end{tabular}

Table 4: Correlation between variables.

As shown in Table 4, it indicates that there is relationship between the inventory management and financial performance. The result was $r=0.683$ that provide strong positive relationship between the variables because the correlation result is greater than 0.50 .

\section{Discussions}

In the first objective, the study results showed that the manufacturing companies use inventory management for information technology and also the respondents provide the researchers that the companies used lead time for purchasing system of inventory. In the 
Citation: Abdikani SA, Mahad MA, Mohamed HD (2018) The Role of Inventory Management on Financial Performance in some Selected Manufacturing Companies in Mogadishu. Int J Account Res 6: 179. doi: 10.35248/2472-114X.18.6.179

Page 6 of 6

second objective, the study found that there is relationship between the inventory management and financial performance. The study indicates the relationship between the variables is positive relationship because the result was $\mathrm{r}=0.683$.

Timothy, Patrick, et al. eximined the impact of inventory management practices on financial performance. The researchers found that there are positive correlation between inventory management practices and financial performance.

Jighyasu and Sourabh studied the relationship of financial and inventory performance of manufacturing firms in Indian context. The researchers categorized the inventory into three major kinds and they are raw materials, work in process and finished goods. The researchers found that finished goods are negatively associated with financial performance while raw materials and work in process have positive relation to the financial performance.

\section{Conclusion}

This study investigated the role of inventory management in financial performance in some selected manufacturing companies in Mogadishu. As the findings showed, the companies used lead time for purchasing system of inventory and also the respondents believe that the companies have computerized all inventory management systems. Also, it shows that the staff of the company is highly skilled for managing the inventory by using information technology.

The study shows that there is relationship between the inventory management and financial performance. The result was $r=0.683$ that provide strong positive relationship between the variables. Means, the two variables moves at same direction.

\section{Recommendations}

The following recommendation have been suggested by the researchers based on the findings in this study

- Managers and staffs of the company should use a proper inventory management system for the company.

- The selected companies should use Point-of-Sale (POS) and Electronic Data Interchange (EDI) in communication and dealing with the customers.

- The company should use Just-In-time (JIT) for purchasing system of inventory and do not maintain too much inventory in the company store.

- Managers must ensure that the company uses enough inventory management tools.

- The company should hire skilled staffs.

\section{References}

1. Vipulesh S (2015) Impact of Inventory Management on the Financial Performance. IOSR J Bus Manage (IOSR-JBM) 7: 1-12.
2. Winnie MN, Ondiek BA (2014) The relationship between working capital management policy and financial performance of companies quoted at Nairobi securities exchange, Kenya. Int J Econ Financ Manage Sci 2: 212-219.

3. Jighyasu G, Sourabh B (2011) The relationship of Financial and Inventory Performance of Manufacturing Firms in Indian Context. Calif J Oper Manage 9: 70-77.

4. Benjamin NO, Daniel MW (2016) Influence of Inventory Control Practices on Procurement Performance of Agrochemicals Distributors in Nakuru Central Sub-County, Kenya. Int J Econ Financ Manage Sci 4: 117-126.

5. Dorothy O, Esther W, Elizabeth WW (2015) Effect of Inventory Management Practices on Organizational Performance in Public Health Institutions in Kenya: A Case Study Of Kenyatta National Hospital. Int J Educ Res 3: 703-714.

6. Dhodi MH (2018) The effect of information technology on inventory management for the manufacturing companies in Mogadishu. Eur J Logist Purch Supply Chain Manage 3: 20-29.

7. Ioannis G, Alina H (2015) Inventory Management and SMEs'Performance before and during the Period of Financial Constraints in Greece: An Empirical Analysis. Int J Res Manage Sci Technol 3: 9-16.

8. Nikola M, Milivoje O, Marina S (2012) Financial Effects of Inventory Management in Trading Companies. Econ Org, 9: 507-519.

9. Godana BE, Ngugi DK (2014) Determinants of Effective Inventory Management at Kenol Kobil Limited. Eur J Buss Manage, 1: 341-361.

10. Dimitris F, Chia-Yi S (2014) Exploring Links among Inventory And Financial Performance In The Agricultural Machinery Industry. Int J Food Agric Econ 2: 1-12.

11. Sayed Jamal AN, Nurul NS, Nabihah AA, Raja Durattum SR (2016) A Study on Relationship between Inventory Management and Company Performance: A Case Study of Textile Chain Store. J Adv Manage Sci 4: 299-304.

12. Kwadwo BP (2015) The impact of efficient inventory management on profitability: evidence from selected manufacturing firms in Ghana. Munich Personal Repec Archive, pp: 1-6.

13. Vohra PS, Dhillon JS (2014) Best Financial Practices Lead Financial Performance of SMES. Int J Account Financ Manage Res (IJAFMR), 4: 5-16.

14. Bhunia A, Mukhuti SS, Roy SG (2011) Financial Performance Analysis. Curr Res J Soc Sci 3: 269-275.

15. Anurag BS, Priyanka T (2012) A study of Financial Performance: A Comparative Analysis of SBI AND ICICI Bank. Int J Mark Financ Serv Manage Res 1: 56-71.

16. Kilonzo JM, Memba FS, Njeru D (2016) Effect of Inventory Management on Financial Performance of Firms Funded by Government Venture Capital in Kenya. Eur J Bus Manage 8: 35-41.

17. Timothy L, Patricka BO, Nebat GM, Virginia KW (2013) The Impact of Inventory Management Practices on Financial Performance of Sugar Manufacturing Firms in Kenya. Int J Bus Humanit Technol, 75-85.

18. Vedran C, Ari-Pekka H, Lawrence AW (2009) On the relationship between inventory and financial performance in manufacturing companies. Int J Operations Production Manage 29: 789-806.

19. Mohamud AM (2011) Inventory management and company's profitability in Selected manufacturing companies in Mogadishu. Kampala. 